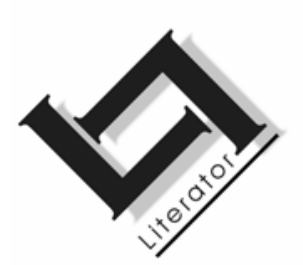

\title{
"Confessing out the soul to conform to the rhythm of thought": a reading of Allen Ginsberg's Beat poetry
}

\author{
Haidee Kruger \\ School of Languages \\ Vaal Triangle Campus \\ North-West University \\ VANDERBIJLPARK
}

E-mail: Haidee.Kruger@nwu.ac.za

\begin{abstract}
"Confessing out the soul to conform to the rhythm of thought": a reading of Allen Ginsberg's Beat poetry

Much critical writing about the Beat Movement has focused on the strong interrelationship between the literary and social discourses within and around the movement. However, the study of Beat literature also necessitates an awareness of its position within the literary discourse of the twentieth century. Beat writing may be seen as standing in the unstable, shifting territory between two equally unstable, shifting literary movements: modernism and postmodernism. Beat poetry pits itself against high modernism and the New Critical tradition, draws upon some aspects of early avant-garde modernism, and simultaneously remoulds these aspects into what may be regarded as the beginnings of postmodernism in the USA. This article presents a reading of Allen Ginsberg's Beat poetry against this literary-historical background. A brief general overview of some of the key characteristics of Beat poetry is given, followed by a discussion of a number of Beat poems, organised around some salient features of Ginsberg's Beat poetry that may be linked to Beat poetry's position in the transition from modernism to postmodernism.
\end{abstract}




\title{
Opsomming
}

\section{"Confessing out the soul to conform to the rhythm of thought": 'n interpretasie van Allen Ginsberg se Beatpoësie}

\begin{abstract}
Kritiese bydraes oor die Beatbeweging fokus dikwels op die sterk verwantskap tussen die literêre en sosiale diskoerse binne sowel as rondom die beweging. Die studie van Beatletterkunde vereis egter ook 'n bewustheid van die beweging se posisie binne die literêre diskoers van die twintigste eeu. Beatpoësie kan beskou word as deel van die onstabiele, veranderlike terrein tussen twee ewe onstabiele, veranderlike literêre bewegings: modernisme en postmodernisme. Beatpoësie verwerp die tradisies van hoogmodernisme en die New Criticism, gryp terug na aspekte van vroeë avant garde-modernisme, en word terselfdertyd deel van wat beskou kan word as die oorsprong van postmodernisme in die VSA. Hierdie artikel behels 'n interpretasie van Allen Ginsberg se Beatpoësie teen hierdie literêr-historiese agtergrond. 'n Kort oorsig van die kerneienskappe van Beatpoësie word verskaf, waarna enkele Beatgedigte bespreek word aan die hand van belangrike eienskappe van Ginsberg se Beatpoësie wat gekoppel kan word aan die posisie van Beatpoësie in die oorgang van modernisme na postmodernisme.
\end{abstract}

\section{Introduction}

Allen Ginsberg's Beat poetry is widely regarded as representative of Beat beliefs and poetics, and over the years he has become the spokesperson and chronicler of the movement. Ginsberg's long publishing career, spanning half a century, suggests the importance of Beat poetics as a continued force in contemporary poetry, also evident in the steady stream of anthologies as well as popular and academic publications about Ginsberg and various aspects of the Beat Movement (see for example Campbell, 1999; Lee, 1996; Morgan, 2000; Peabody, 1997; Raskin, 2005; Sanders, 2000).

Much critical writing on the Beats has focused on the strong interrelationship between the literary and social discourses within and around the movement, with the emphasis often falling on the effects that the Beats' literary discourse had on the social discourse of the USA of the 1950s and the development of countercultural movements (see for example Charters, 1993; George \& Starr, 1985). However, the study of Beat literature also necessitates an awareness of its position within the literary discourse of the twentieth century. Beat writing may be seen as standing in the unstable, shifting territory between two equally unstable, shifting literary move- 
ments: modernism and postmodernism. Beat poetry pits itself against high modernism, draws upon some aspects of early avantgarde modernism, and simultaneously remoulds these aspects into what may be regarded as the beginnings of postmodernism in the USA (see Russell, 1985:242; Huyssen, 1986:188). Calinescu (1987a:297) summarises these ideas:

the term postmodernism first came into literary use in the United States, where a number of poets of the later 1940s used it to distance themselves from the symbolist kind of modernism represented by T.S. Eliot. Like the early postmoderns, most of those who subsequently joined the antimodernist reaction were aesthetic radicals and often close to the spirit of the counterculture. The works of these writers constitute the historical nucleus of literary postmodernism. In poetry the corpus of American postmodernist writing would include the Black Mountain poets ... the Beats ... and the representatives of the San Francisco Renaissance ... or those of the New York school ...

It also needs to be pointed out that the high modernist legacy of formalism, conservatism, erudition, classicism, detachment, intellectualism and impersonality (Charters, 1993:586; Holmes, 1981:5) formed a powerful alliance with the dominant tradition of literary criticism in the post-World War II literary climate in the USA: New Criticism. The New Critics asserted that "the essential property of poetry consists in the reconciliation or harmonization of opposites; that this takes the form of an objective organization of the objective meanings of words" (Robey, 1986:84). This, together with the legacy of high modernism, created expectations of literature centring on impersonality, objectivity, ironic detachment and formal refinement.

Ginsberg's Beat poetry flouted almost every convention institutionalised by the coalition between high modernist poetics and New Criticism. His poetry is aggressively personal, highly emotional, and almost always excessive in style and content. His explicit depiction and celebration of homosexuality, crime and drug use are in conflict with the relatively conservative notions of morality implicitly espoused by New Criticism. As far as style is concerned, Ginsberg's writing is unrestrained, rhapsodic, excessively emotional and declarative, without the delicate intellectual nuances of construction valued by high modernist poetics and New Criticism. 
This article presents a reading of Allen Ginsberg's Beat poetry 1 against this background. A brief general overview of some of the key characteristics of Beat poetry is given, followed by a discussion of a number of Beat poems, organised around some salient features of Ginsberg's Beat poetry that may be linked to Beat poetry's position in the transition from modernism to postmodernism.

\section{An overview of the key characteristics of Beat poetry}

Charters (1993:582) regards the Beats' "rebellious questioning of conventional American cultural values during the cold war" as the single most important thematic characteristic of their writing. The Beats strove to counter social conformity with a belief in the sanctity of the individual experience, repression with spontaneity and freedom of experience and expression, and materialism with spirituality. These general aims and beliefs had particular effects on both the content and the style of Beat writing.

Firstly, in terms of style, one of the most important projects of the Beat writers was to create a spontaneous creative style, an "aesthetic of unguarded, untrammeled expression" (Stephenson, 1990:14). Kerouac was the main influence in this project, the aims of which he set out in two accounts: "Essentials of spontaneous prose" and "Belief and technique of modern prose". In the former he states the basic idea of spontaneous prose as "not 'selectivity' of expression but following free deviation (association) of mind into limitless blow-on-subject seas of thought, swimming in sea of English with no discipline other than rhythms of rhetorical exhalation and expostulated statement ..." (Kerouac, 1995:484).

Ginsberg has acknowledged his debt to what he has called Kerouac's "spontaneous bop prosody" (Clark, 1970:131-132). Many of the structural characteristics of Beat writing can be linked to this quality, such as the surreal juxtaposition of chains of images, the use of organic speech rhythms, and the predominance of improvisatory, rambling poetic forms (Holmes, 1981:11).

1 The definitive Beat phase of Ginsberg's writing is generally dated as 1947-1959, with its culmination in the publication of the volume Howl and other poems (1956). This dating follows the categorisation in Allen Ginsberg: collected poems 1947-1985 (Ginsberg, 1984a). All references to poems are from this source, which is subsequently abbreviated as $\mathrm{CP}$. 
A second important characteristic of the Beats' writing is their ideal of "making personality the center and subject of their work" (Tytell, 1976:15). In one sense, this may be regarded as a direct reaction against the ideal of impersonality and objectivity established by the modernist legacy of Eliot and Pound. In another, wider sense, this aspect of their writing can be traced back to their conflict with contemporary American civilisation, which they regarded as warped and sterile, partly because of its emphasis on collectivity, conformity, materialism and conservatism. Like Whitman, and the American transcendentalists Emerson and Thoreau, the Beats believed that only individual experience and spirituality could possibly give some meaning to existence in a sterile society (Tytell, 1976:4).

The emphasis on individuality gives rise to a poetry that is generally antiformalist, in the sense that it does not see form as an external imposition, "an overlay you scissored the raw edges of content to fit" (Holmes, 1981:7). Instead, the aim is intuitively to find a rhythm and language inherent to the self and its personal expression. Another characteristic linked to the emphasis on subjectivity is the importance attached to the actual voice of the poet and the consequent development of poetry as oral performance.

A third general characteristic of Beat poetry is the emphasis placed on freedom of experience and expression, which resulted primarily from the Beats' reaction against a conformist society. In terms of the content of Beat poetry, this is linked to the Beats' description of the lifestyle of the counterculture, incorporating taboos such as drugs and homosexual relationships. On the formal level, Beat writing displays the writers' insistence on personal freedom in many respects. Essentially, it entails the freedom to break with established conventions of literary form, and to invent and experiment with new forms. Kerouac's rambling picaresque narratives, Burroughs's cut-up and fold-in techniques and Ginsberg's experimentations with free incantatory verse are all ways of breaking with the conventions of literary form (Stephenson, 1990:10).

A final defining trait of Beat poetry is its concern with spirituality. Everson (1981:182) describes the Beat project as an attempt to "incorporate genuine ecstatic and mystical needs" into everyday existence. In doing so, the Beats returned to the shamanisticprophetic role of the artist in society (Stephenson, 1990:15). They were also particularly attracted to Eastern, "primitive" and mystical religious traditions. In Ginsberg's case, there is a strong link with Judaism, but he also studied, among others, gnosticism, mysticism, native American lore, Hinduism and Buddhism (Prothero, 1991:216; 
Portugés, 1984:143). In particular, his eclectic appropriation of Buddhist principles and other Eastern systems of belief has been a pervasive influence on both the content and the form of his poetry (George \& Starr, 1985:196; Jackson, 1988).

The above broad characteristics of Beat poetry find their precipitation in Ginsberg's Beat poetry in various ways, many of which may be related to Beat poetry's position as simultaneously anti-highmodernist and early postmodernist. Beat poetry is essentially driven by a counterhegemonic and activist impulse, and is a celebration of difference, heterogeneity and contradiction. On a formal level, this finds its expression in experimentalism, improvisation and innovation. On a social level, Beat poetry's activism links with its social involvement and its keen interest in mass culture, a defining characteristic of postmodernist art. This also ties in with the emphasis that is placed on poetry as popular art form, meant to be performed. Another significant feature of Ginsberg's poetry is the importance attached to delight and play - a feature that may be linked to Beat poetry's rejection of the pessimistic and austere image of poetry associated with high modernism. Beat poetry's celebration of immediacy, intensity and irrationality may also be related to this. A last characteristic of Ginsberg's poetry that warrants attention in terms of its relationship to postmodernism is its intertextuality.

In the following section, the above qualities are discussed in more depth, with particular attention to selected poems.

\section{Beat poems: readings}

\subsection{The counterhegemonic impulse, activism and anarchism}

As a whole, Ginsberg's Beat poetry is a celebration of marginalised culture. Gilmore (1997:36) emphasises the role of Ginsberg's poetry in "the freeing up of people and voices that much of established society wanted kept in the margins". The ultimate purpose of much of Ginsberg's Beat poetry is to expose the fallacy of American culture as homogenously middle-class and heterosexual, by foregrounding variety and difference. At the same time, it undermines the hegemony of various other basic assumptions or beliefs upon which Western society is founded, such as the superiority of the ego, and the authority of order, meaning, control, identity and reason. In postmodernist terms, Ginsberg's Beat poetry may therefore be regarded as reflecting a resistance against totalising metanarratives (see Lyotard, 1984; 1993). 
On the level of the individual, Beat poetry resists the traditional definition or metanarrative of the self as ego or fixed point of identity, primarily defined by virtue of its capacity to reason. In "Over Kansas" (CP:116-119) the traditional concept of self as ego is denied, when the poet unequivocally states that "I am no ego" (I. 4), a sentiment echoed in line 8 of "Siesta in Xbalba" (CP:97-110): "let the mind fall down". Instead Ginsberg's Beat poetry plays with the notion of self, arguing that transitory physical and emotional experience, together with mystical and visionary states, might constitute an alternative locus for the self. This idea is articulated in an early poem, "Psalm I" (CP:18):

These psalms are the workings of the vision haunted mind and not that reason which never changes.

I am flesh and blood but my mind is the focus of much lightning.

I change with the weather, with the state of my finances, with the work I do, with my company.

But truly none of these is accountable for the majestic flaws of mind which have left my brain open to hallucination (I. 1-4).

On a social level, the counterhegemonic nature of Beat poetry is apparent from its resistance against social control and the dominance of a particular group and its ideology. It contests any view of society as a monolithic entity and resists totalisation, instead celebrating plurality and diversity. "Howl" (CP:126-133) is exemplary of this. The poem is an outcry against the stultifying conventional assumptions of middle-class America, embodied in the god Moloch, who dominates the second section of the poem. Moloch may be regarded as a personification of the metanarratives upon which Western society is constructed. Moloch is "the Mind" (I. 84), which destroys "brains and imagination" (I. 78), in which the self is "a consciousness without a body" whose fate is "a cloud of sexless hydrogen" (I. 84). Moloch is also the desire for progress, regardless of the consequences:

Moloch whose mind is pure machinery! Moloch whose blood is running money! Moloch whose fingers are ten armies!

Moloch whose breast is a cannibal dynamo! Moloch whose ear is a smoking tomb!

Moloch whose eyes are a thousand blind windows! Moloch whose skyscrapers stand in the long streets like endless Jehovahs! Moloch whose factories dream and croak in the fog! Moloch whose smokestacks and antennae crown the cities!

Moloch whose love is endless oil and stone! Moloch whose soul 
is electricity and banks! Moloch whose poverty is the specter of genius! (I. 82-84).

This second section of "Howl" exposes and questions some of the basic metanarratives on which Western society is based, by drawing their consequences as negative and destructive. It links the primacy of reason with a social ethics based on capitalist exploitation and ruthless progress, and presents the results of these as a terrifying society of "Robot apartments! invisible suburbs! skeleton treasuries! blind capitals! demonic industries! spectral nations! invincible madhouses! granite cocks! monstrous bombs!" (I. 87).

The poem thus rejects the hegemony of these basic metanarratives as numbing, stifling and ultimately destructive. Its counterhegemonic gesture consists of pushing that which has been marginalised and hidden to the foreground. Instead of the dominance of order and reason, the poem celebrates extremities of chaotic and intense experience: physical, emotional and spiritual:

with dreams, with drugs, with waking nightmares, alcohol and cock and endless balls,

incomparable blind streets of shuddering cloud and lightning in the mind leaping towards poles of Canada \& Paterson, illuminating all the motionless world of Time between,

Peyote solidities of halls, backyard green tree cemetery dawns, wine drunkenness over the rooftops, storefront boroughs of teahead joyride neon blinking traffic light, sun and moon and tree vibrations in the roaring winter dusks of Brooklyn, ashcan rantings and kind king light of mind, (l. 11-13).

All of these experiences are depicted in terms of an absence of control, since control implies some kind of hierarchical structuring of experience. In this process the poem makes a deconstructionist move by inverting the hierarchy and placing the repressed terms (spirit, emotion, body) in the primary position, celebrating the

angelheaded hipsters burning for the ancient heavenly connection to the starry dynamo in the machinery of night,

who poverty and tatters and hollow-eyed and high sat up smoking in the supernatural darkness of cold-water flats floating across the tops of cities contemplating jazz, who bared their brains to Heaven under the El and saw Mohammedan angels staggering on tenement roofs illuminated (I. 3-5). 
The activist and anarchic tendency of Beat poetry is closely linked to the above, and may be regarded as typical of early postmodernism's "expression of a defensive rage and creative idealism" (Russell, 1985:254). A particularly powerful activist poem written in Ginsberg's Beat phase is "America" (CP:146-148). In this poem Ginsberg criticises American society on several grounds, using a technique of "one-liners in different voices, sardonic schizophrenic, the tone influenced by Tzara's Dada manifestos" (Ginsberg, 1995). He condemns it for its obsession with technological warfare that destroys human beings (I. 4-5, 17), while simultaneously deploring its unwillingness to embrace qualities such as spirituality, honesty and tolerance (I. 8-14). He furthermore criticises the fundamental xenophobia of conservative American society, by parodying stereotypical paranoid representations of countries like Russia and China (I. 6366). This paranoia and intolerance are coupled with excessive materialism (I. 56, 65-66) and emotional barrenness (I. 39).

The "I" of the poem then (often ironically and humorously) places himself in an oppositional stance. Instead of economic wealth, military power and technologically advanced weaponry, his "national resources" (I. 49) consist of

two joints of marijuana millions of genitals an unpublishable private literature that jetplanes 1400 miles an hour and twentyfive-thousand mental institutions.

I say nothing about my prisons nor the millions of underprivileged who live in my flowerpots under the light of five hundred suns (I. 50-51).

Instead of working seriously and responsibly to amass wealth, he smokes marijuana and stays at home, doing nothing but "stare at the roses in the closet" (I. 30). Finally, instead of the emotional and spiritual superficiality of American society, the poet-speaker consistently exhibits a concern for authentic and sincere emotion and spirituality (I. 36) and compassion for all people (I. 13, 50-51).

The last three lines of the poem contain an explicit (though selfdeprecating and ironic) personal commitment to change this society - not by participating in its institutions, but by a personal (most probably poetic) effort:

l'd better get right down to the job.

It's true I don't want to join the Army or turn lathes in precision parts factories, I'm nearsighted and psychopathic anyway.

America I'm putting my queer shoulder to the wheel (I. 71-73). 
This commitment to exposing the wrongs of society and actively trying to create solutions and initiate changes pervades much of Ginsberg's poetry. "Death to Van Gogh's ear" (CP:167-170) is another example of such a poem. The underlying assumption of poems such as these is that poetry should make social injustice its business, and moreover, that poetry has the power to exert some kind of influence on society. This belief is also apparent in Ginsberg's continual practical and poetic involvement with numerous activist groups, campaigning for human rights, peace, environmental issues and gay rights (see Austin, 1995; Carter, 2001; Moore, 1997).

\subsection{Experimentalism, improvisation and innovation}

Russell (1985:240) points out that formal experimentalism often originates from a desire to find a new voice by violating the constraints of the patriarchal, bourgeois, dominant culture's language and modes of expression. Whereas the acceptance of metanarratives expresses itself formally in closure, totalisation and unity (as embodied in the New Critical idea of the well-made poem), the postmodernist stance towards metanarratives expresses itself in forms that are discontinuous, improvisatory, open and playful. This is the basis of the formal experimentation of Ginsberg's Beat poetry. In particular, his use of the long line or breath unit (together with cataloguing, litany-like repetition and lavish accumulation of language) is a way of challenging the New Critical convention of the carefully contained poem. This experimental technique is probably the most characteristic and innovative formal aspect of Ginsberg's poetry, and is present in the majority of his important Beat poems, like "Howl" (CP:126-133), "A supermarket in California" (CP:136) and "Sunflower sutra" (CP:138-139). In most of these poems it is as if the expansiveness of the vision cannot be contained within the confines of traditional poetic form, but spills over into a profusion of words and images linked in one breath. Ginsberg has explained that this is the result of his dictum of "first thought, best thought", which is a way of capturing the "[s]pontaneous insight - the sequence of thought-forms passing naturally through ordinary mind" (CP:xx). In "Howl" (CP:126-133) this idea is metatextually described as follows:

who dreamt and made incarnate gaps in Time \& Space through images juxtaposed, and trapped the archangel of the soul between 2 visual images and joined the elemental verbs and set the noun and dash of consciousness together jumping with sensation of Pater Omnipotens Aeterna

Deus, to recreate the syntax and measure of poor human prose and stand before you speechless and intelligent and 
shaking with shame, rejected yet confessing out the soul to conform to the rhythm of thought in his naked and endless head, (I. 73-74).

There are many other experimental techniques evident in Ginsberg's poetry, such as making the whole poem one long sentence with little or no punctuation, as in "Europe! Europe!" (CP:171-173):
World world world
I sit in my room
imagine the future
sunlight falls on Paris
I am alone there is no
one whose love is perfect
man has been mad man's
love is not perfect I
have not wept enough
my breast will be heavy
till death the cities
are specters of cranks
of war ... (l. 1-13).

In other poems, such as "Laughing gas" (CP:189-199), long lines, continuous lines and broken lines are mixed in a way that seems completely formless. In some cases, the experimentation becomes extreme, resulting in poems approaching the style of concrete poetry, such as the poem "Funny death" (CP:200).

Ginsberg's use of contemporary informal language and specifically American speech rhythms, constitutes another important experimental technique. In this the influence of William Carlos Williams is crucial, though of course there are vast differences between Williams's and Ginsberg's styles. Ginsberg has repeatedly acknowledged his debt to Williams in this regard (see Géfin, 1984:274), but has also said that what distinguishes his style from that of Williams is his "Hebraic-Melvillian bardic breath" (Ginsberg, 1984b:81) and his "feeling ... for a big long cranky statement" (in Clark, 1970:136). Ginsberg's use of everyday colloquial language, slang and expletives, mixed with the incantatory Jewish tradition and declamatory Biblical style (particularly evident in poems such as "Howl"; CP:126133 and "America"; CP:146-148) was a reaction against the New Critical convention of the contained poem and the elitism and intellectualism of high modernism, and reflects early postmodernism's concern with free, open and eclectic forms of expression. 


\subsection{The influence of mass culture}

While various critics and groups, such as the New Critics, have viewed twentieth-century popular culture as a threat to refined and enlightened minds, one of the main projects of postmodernism has been to undo this dichotomy between works designed for popular consumption and so-called high art (Calinescu, 1987a:285). The Beat ethos of the 1950s and 1960s aimed to bring poetry back to the people, to de-academise it and re-connect it, as performative art, to the community. Beat poetry played a significant role in the development of the American countercultural movement during the 1950s for the precise reason that it was essentially populist, created to draw and involve listeners/readers. This tendency is also obvious in Ginsberg's collaborations with many popular artists, including Bob Dylan, The Clash, Kim Deal (formerly from cult indie band The Pixies) and U2 (Smith, 1996). The populist, open and accessible aesthetic of Beat poetry is reflected in its informal diction, its speech rhythms, its performative nature, its simultaneous personal and social consciousness, its explicit connections to everyday life, and its mix of criticism, humour and idealism.

Apart from the fact that Beat poetry is essentially popular poetry, its connections with popular culture are multifarious. The Beats and their poetry have always been fascinated by popular culture. In poems such as "The blue angel" (CP:54) and "America" (CP:146148) the references to mass culture create a largely negative reflection on the commodification of emotion by popular culture. In "The blue angel" Marlene Dietrich becomes a symbol of "mechanical love" (I. 2), a product of a culture in which people allow their "emotional life [to] be run by Time Magazine" ("America"; CP:146148). This negative view of popular or consumer culture becomes even clearer in "Death to Van Gogh's ear!" (CP:167-170):

Hollywood will rot on the windmills of Eternity

Hollywood whose movies stick in the throat of God

Yes Hollywood will get what it deserves

Time

Seepage of nerve-gas over the radio (1. 50-54).

However, considering the Beats' own populist impulse, it would seem as if it is not the notion of popular culture as such that is criticised, but rather what contemporary American society has made of popular culture. All in all, Beat seems to stand for a popular, widely dispersed culture that embraces positive spiritual values such as honesty, spirituality, love and sensitivity. Positive references to 
icons of popular culture are often used to express this idea. In "POEM rocket" (CP:163-164) the speaker refers to Albert Einstein: "O Einstein I should have sent you my flaming mss. I O Einstein I should have pilgrimaged to your white hair!" (I. 15-16). The same positive reference to Einstein is found in line 23 of "Death to Van Gogh's ear!" (CP:167-170), coupled with a reference to "immortal" Charlie Chaplin who was "driven from our shores with the rose in his teeth" (I. 25). In "Ignu" (CP:203-205) Harpo Marx is classified together with (among others) Walt Whitman, Charles Dickens, William Carlos Williams and William S. Burroughs in the category of ignu "angel in comical form" (I. 5). Figures such as these appear as representations of the imaginative individual countering the deceitfulness, decay and apathy of contemporary mass culture.

Apart from positive and negative associations with popular culture, there are many poems in which there is no real value judgement attached to elements from popular culture where the popular consciousness merely blends with the personal consciousness. Such a poem is "Laughing gas" (CP:189-199), where the Loony Tunes and Woody Woodpecker make an appearance (I. 37), Santa Clauses (I. 45) mingle with Christs and Buddhas (I. 42), while Mickey Mouse cartoons assume apocalyptic overtones (I. 67-69). There are clichéd fragments of popular texts: "It was a dark and gloomy night ..." (I. 76) and "You take the high road / and I'll take the low"' (I. 7980), while the Cheshire Cat (I. 180) appears together with Frank Sinatra (I. 200-209), and President Eisenhower (I. 225). All of these references contribute to integrate an awareness of the social and political environment with the personal consciousness.

\subsection{Delight, play, performance}

One of the main distinctions between modernism and postmodernism is the latter's inclusion, exploration and affirmative revaluation of elements of delight, enjoyment, play, chance and performance (Calinescu, 1987a:284; Fiedler, 1992:35). In a way, this dimension of postmodernism is a reaction against the sober, serious and largely negative perception of high modernism, so that postmodernism comes to regard itself as "a joyous rebirth of diversity after the austere negativity of modernism" (Calinescu, 1987b:7). Ginsberg's Beat poetry certainly reconnects art with enjoyment and often introduces an element of playfulness. Some poems rely on an almost whimsical play with words and sounds together with sexual innuendo for their playfulness. The two poems 
"Fie my fum" (CP:23) and "Pull my daisy" (CP:24-25) are exemplary. The last three stanzas of the former poem are typical:

Whore my door,

Stone my dream,

Milk my mind

And make me cream,

Say my oops,

Ope my shell,

Roll my bones,

Ring my bell,

Pope my parts,

Pop my pot,

Poke my pap,

Pit my plum (I. 17-28).

In the last stanza, alliteration, together with the playful associative metamorphoses of words, is particularly important. It accounts for the transformation from "pope" to "pop" to "poke" to "pit", running parallel with the transformation from "parts" to "pot" to "pap" to "plum". The changes seem entirely arbitrary, as if selected on the basis of chance association, but sustain the sexual suggestion. The same processes are at work in the previous stanza, but here they seem to work diagonally as well as vertically. In lines 21-22 the transformative and alliterative process works diagonally, so that "say" becomes "shell" and "oops" becomes "ope". In lines 23-24, vertical alliteration is again more important, with "roll" linking with "ring", and "bones" with "bell". The whole stanza (like all the others) is held together by broken rhyme, with the second and fourth lines of each quatrain rhyming.

In other poems the lightheartedness is based less on form, and more on the humour, irony or absurdity of the content. "The archetype poem" (CP:61-62) and "A typical affair" (CP:63) both deal with failed relationships in a light-hearted and ironically distanced manner. In "Four haiku" (CP:137) the humour is based on the banal and the absurd:

Looking over my shoulder

my behind was covered

with cherry blossoms (I. 1-3).

"A supermarket in California" (CP:136) has a kind of wistful lightheartedness created by the absurd images and mischievous references to Whitman's "eyeing the grocery boys" (I. 4). 
Ginsberg's Beat poetry displays an awareness of the critical power of humour, irony and parody. This is particularly apparent in "America" (CP:146-148). The social criticism of this poem has already been discussed, but it is important to note that the poem uses humour, irony and parody to present its irreverence and incisive critique. From the crude humour of "Go fuck yourself with your atom bomb" (I. 5) to the coyness of "When can I go into the supermarket and buy what I need with my good looks?" (I. 15); from the wry irony of "My ambition is to be President despite the fact that I'm a Catholic" (I. 53) to the deliberately shocking parody of "That no good. Ugh. Him make Indians learn read. Him need big black niggers" (I. 67), the poem uses various humorous devices to expose the corruption of American society.

A last point to be made here is that the notions of voice and performance are crucial to the Beat ethos. Beat poetry is intended to be read aloud, as Ginsberg's many performances over the years attest (see Asher, 1997; Moore 1997). There are also some poems that are intended as songs (with music included), like "A Western ballad" (CP:13) and "Green Valentine blues" (CP:95-96). In later years, Ginsberg also set many of his poems to music, some of which have been recorded. 2

\subsection{Immediacy, intensity and irrationality}

In content as well as expression, Ginsberg's Beat poetry is an attempt to transmit the immediate, be it physical, emotional or spiritual. It is, as Altieri (1996:775) points out of postmodernist poetry in general, poetry that is "direct habitation, a directly instrumental rather than contemplative use of language. And its test of value becomes the mobility and intensity immediately made available to the poet ..." Linked to this is early postmodernist writing's emphasis on the intuitive rather than the analytic. As Fiedler (1992:33) puts it, early postmodernism is often "apocalyptic, antirational, blatantly romantic and sentimental ... distrustful of selfprotective irony and too great self-awareness".

Ginsberg's early poems written in the William Carlos Williams imagist style are attempts to reflect the immediacy of the sensory experience, together with its emotional, intellectual and spiritual

2 In 1995 Ginsberg released a four-CD box set entitled Holy soul jelly roll - poems and songs 1949-1993. The set contains recordings from many performances over the years, retrieved mostly from personal archives. 
connotations (see "The bricklayer's lunch hour"; CP:4). However, it is in poems such as "Howl" (CP:126-133) that the emphasis Beat writing places on immediacy, intensity and irrationality comes to the foreground most powerfully. The first part of the poem centres on descriptions of individuals searching for meaning in extremes of physical, emotional and spiritual experience. The intense physicality of experience is suggested by descriptions of "starving hysterical naked" people (I. 1) "dragging themselves through the negro streets ... looking for an angry fix" (I. 2) and "ecstatic and insatiate" sex (I. 41). The high incidence of verbs depicting vigorous, intense action and feeling is a technique used to convey this intensity. Furthermore, the construction of the poem places these verbs in a repetitive configuration which has a cumulative effect, heightening the intensity with each repetition. For example, from line 48-65 the following constructions appear at the beginning of each line:

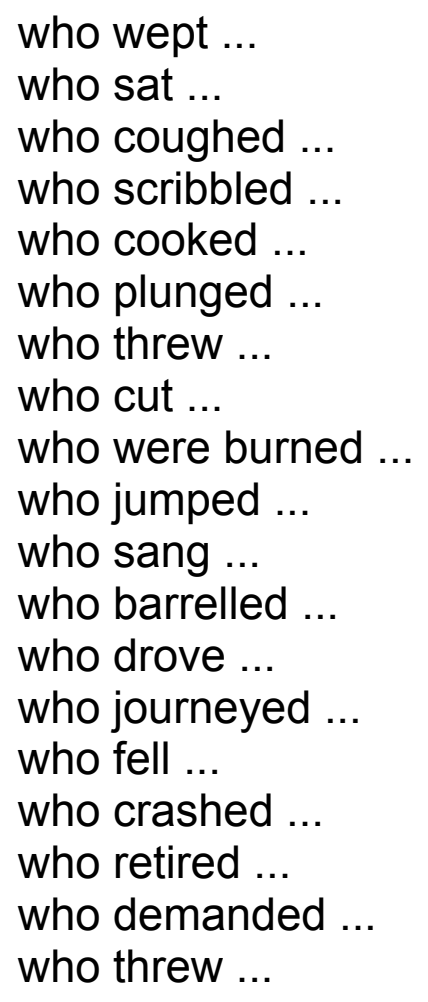

Emotion is also strongly emphasised as a basic and essential constituent of human experience, as in the following lines:

who broke down crying in white gymnasiums naked and trembling before the machinery of other skeletons, who bit detectives in the neck and shrieked with delight in policecars for committing no crime but their own wild cooking pederasty and intoxication,

who howled on their knees in the subway and were dragged off the roof waving genitals and manuscripts, (I. 33-35). 
Spirituality similarly receives a very strong emphasis. The poem contains many descriptions of spiritual experience, such as: "incomparable blind streets of shuddering cloud and lightning in the mind" (I. 11), "sun and moon and tree vibrations" (I. 13), "visionary indian angels" (I. 25), "telepathy and bop kabbalah" (I. 24) and "supernatural ecstacy" (I. 26).

The immediacy, intensity and irrationality of physical, emotional and spiritual experience are conveyed not only by the long lines and incantatory structure, but also by the surreal juxtaposition of images, which reflects both the immediacy and irrationality of experience and the immediacy and irrationality of the writing process, reflected in the Beat mantra of "first thought, best thought" (CP:xx).

The above examples clearly suggest the sense of physical excess and emotional and spiritual intensity that saturates the poem. These emphases are placed in opposition with the negative appraisal of the intellect. The universities and academies with their "scholars of war" (I. 6) are described as being unable to comprehend the full scope of experience, which includes intense beauty, horror, madness, hallucination, fantasy and creative power (I. 6-7). The mind is also linked with the evil, death and destruction associated with Moloch, who annihilates all imagination, sensual pleasure, compassionate emotion and creative and spiritual potential (I. 85-87).

Against Moloch is pitted the individual who strives to revive the neglected and suppressed dimensions of experience, of necessity involving extremities and intensities of experience that are in conflict with Moloch's sanitation and regimentation of experience. Consequently these individuals are labelled "mad" by societal constrictions. However, the Beats regarded madness in a positive light, along the lines of Antonin Artaud's definition of a lunatic as "a man who has preferred to become what is socially understood as mad rather than forfeit a certain superior idea of human honor" (quoted in Watson, 1995:115). "Howl" is a tribute to this idea. It is dedicated to the poet Carl Solomon, whom Ginsberg met when they were both in the Columbia Presbyterian Psychiatric Institute (Watson, 1995:112), and who became a Beat icon for his defiance of norms and conventions. The poem describes some of Solomon's exploits:

who threw potato salad at CCNY lecturers on Dadaism and subsequently presented themselves on the granite steps of the madhouse with shaven heads and harlequin speech of suicide, demanding instantaneous lobotomy, 
and who were given instead the concrete void of insulin Metrazol electricity hydrotherapy psychotherapy occupational therapy pingpong and amnesia, (I. 65-66).

In the last section of "Howl", Solomon is apostrophised, using a repetitive incantatory structure starting with "I'm with you", suggesting the speaker's allegiance to Solomon's anti-establishment commitment to the intensity of experience:

I'm with you in Rockland

where we wake up electrified out of the coma by our own souls' airplanes roaring over the roof they've come to drop angelic bombs the hospital illuminates itself imaginary walls collapse $O$ skinny legions run outside O starry-spangled shock of mercy the eternal war is here $\mathrm{O}$ victory forget your underwear we're free (l. 127-128).

The immediacy, intensity and irrationality of Ginsberg's Beat poetry are further reflected in the numerous poems dealing with dreams, visionary experiences, hallucinations and spiritual experiences, such as "Back on Times Square, dreaming of Times Square" (CP:188), "Siesta in Xbalba" (CP:97-110), "Sunflower sutra" (CP:138-139), "Sather Gate illumination" (CP:142-145) and "Laughing gas" (CP: 189-199).

\subsection{Intertextuality}

The intertextuality of Ginsberg's Beat poetry is part of its reaction against such ideas as the autonomy of the "well-made poem". Ginsberg's Beat poems deliberately place themselves within the flux of discourse - be it artistic, social, political, or from the present or the past. This involves stretching and dissolving the boundaries of the poem, engaging it in a polylogue with other texts, resulting in poems that are intentionally and often excessively polyphonic.

The most explicit instances of intertextuality in Ginsberg's poetry are those that relate to artistic texts, mostly in the forms of literary and visual art. However, as will become apparent in the following discussion, Ginsberg's typical intertextual technique assumes a very idiosyncratic form. Instead of incorporating fragments of other texts into his own poems, or playing with the material of other texts in the form of comment, parody and pastiche, he uses strategically selected words (often proper nouns) which function as the nodes by which elaborate texts are activated and engaged. 
In some poems the intertextual links are quite obvious, as in "On reading William Blake's 'Sick rose"' (CP:6). In others the intertextual dynamic is subtler. "Bop lyrics" (CP:42-43) contains an oblique reference to the poet Christopher Smart in its refrain of "Smart went crazy / Smart went crazy" (I. 6-7, 13-14). This is the only reference in the poem, but the mention of the name activates a conglomerate of texts, which then feed into "Bop lyrics" (which then feeds back into these texts again). Smart was an eighteenth-century poet, whose life and poetry show much similarity to Ginsberg's (see Hunsberger, 1984). Both poets had interludes of what was classified as madness, and like Ginsberg's, Smart's poetry is concerned with the visionary and the spiritual, intermingled with details from everyday life. It is also strikingly alike in form to Ginsberg's, with similar long lines and repetitive structures. Consider the following example, from "Jubilate agno" (in Allison et al., 1983:470-471):

For I will consider my Cat Jeoffry.

For he is the servant of the living God, duly and daily serving him.

For at the first glance of the glory of God in the East he worships in his way.

For this is done by wreathing his body seven times round with elegant quickness.

For then he leaps up to catch the musk, which is the blessing of God upon his prayer.

For he rolls upon prank to work it in.

For having done duty and received blessing he begins to consider himself.

For this he performs in ten degrees.

For first he looks upon his forepaws to see if they are clean.

For secondly he kicks up behind to clear away there.

For thirdly he works it upon stretch with the forepaws extended (I. 697-707).

Once the reference to Smart has activated the additional text of his poetry and life, "Bop lyrics" (CP:42-43) explicitly becomes part of a dialogue with the older text. This is particularly evident in the last stanza (which also intertextually links with the poem "Fie my fum"; $\mathrm{CP}: 23)$ :

I'm a pot and God's a potter,

And my head's a piece of putty,

Ark my darkness,

Lark my looks,

I'm so lucky to be nutty (I. 30-34). 
The same process is followed in a poem like "I have increased power" (CP:68-69) which explicitly establishes multiple intertextual links, involving references to Hemingway (I. 2-3), Shakespeare (I. 12-20) and Carl Solomon (I. 35-40). These three references act like hyperlinks, allowing the poem to branch out in many other directions, following (an infinite number of) links to other texts. This denies the idea of the poem as closed artefact and instead places it within the flux of discourse. The poem then becomes not only Ginsberg's musing on death and time, but a point where several texts with related ideas intersect.

"Death to Van Gogh's ear!" (CP:167-170) and "At Apollinaire's grave" (CP:180-182) apply this technique more extensively by incorporating multiple references to other artists, so that the poem becomes a multi-layered, polyphonic point of intersection. In the latter poem, Ginsberg places himself and his writing in the company of various artists, making the intertextual relationships between texts very explicit. The focus falls on Apollinaire, but the speaker's thoughts while sitting at Apollinaire's grave leads him to invoke the names of many other artists as well: Jacob (I. 36), Picasso (I. 37), Rousseau (I. 38), Tzara (I. 40), Breton (I. 44), Cendrars (I. 46), Vaché (I. 47), Cocteau (I. 48), Rigaut (I. 49), Gide (I. 50), Whitman (I. 52) and Mayakovsky (I. 57). In line 11 the idea of intertextual layering is expressed: the speaker wishes to pay homage to Apollinaire by laying "my temporary American Howl on top of his silent Caligramme".

Ginsberg's poetry clearly expresses an awareness that all texts are related and are continually conversing with one another. However, it needs to be emphasised that Ginsberg's version of intertextuality has a very particular slant, having less to do with a self-conscious attempt to foreground textuality and textual relationships, and more with a need to express the impact of certain texts (be they artistic, social or personal) on his poetic development.

\section{Conclusion}

This article has presented a reading of selected Beat poems by Allen Ginsberg, proceeding from the assumption that Beat poetry can be regarded as a reaction against the institutionalised, academicised form of high modernism in the USA of the 1950s. In this anti-modernist reaction the beginnings of postmodernism may be found. However, viewing Beat poetry purely as anti-modernist and early postmodernist is, of course, a reified, convenient construction of Beat, which facilitates a discussion of the poetry in terms 
of its position and role in twentieth-century literary developments. The relationships between Beat, modernism and postmodernism are complex and heterogeneous. For example, while Beat poetry embodies a definite reaction against the intellectualism, elitism and objective style of high modernist poetry, Beat's indebtedness to modernist poetics is also indisputable. Ginsberg himself has acknowledged this, pointing out the influence of writers like William Carlos Williams and Ezra Pound. While he acknowledges some of Eliot's innovation and influence in terms of the use of language, he states in an interview with Pivano (2001:117) in 1968 that "Eliot never solved the verse form problem for us ... he never solved the problem of how do you register American speech?". According to Ginsberg, he and his fellow post-World War II poets "came in ... on the coattails of the classicists, of Pound and Williams and Marianne Moore" (Pivano, 2001:117), who, in their very different ways, worked towards new forms to express a new reality and a new language. Ginsberg describes the process of pursuing the direction that these writers set out in as follows:

... I don't know if we added anything basic, because Pound's was the first great discovery of the change. The only thing I think is, we learnt the lesson. We were the first generation after them to learn the lesson and begin applying to our own conditions, our own provincial speeches, mouths of Denver and New Jersey, our own personal physiologies and personal breathing rhythms, and to our own police state postwar Buck Rogers Newspeak universal conditions of local ecstasy of godrealization (Pivano, 2001:118).

Ginsberg therefore suggests the double-sided relationship of Beat with the modernist inheritance. Despite its rejection of high modernist poetics, Beat is also a continuation of the avant-garde dimension of modernism, as Ginsberg points out in the same interview with Pivano (2001:112):

So actually experimental prosody has been the main tradition in American and English poetry for the better part of this last century. And so one may say that it is the 'Tradition' that the younger poets in America are working on, it's the 'real tradition'. And the paradox is that these younger poets who were working in this tradition have been accused of being aesthetic anarchists, of not working in any 'tradition' at all. Unfair! Ignorant accusation!

Ginsberg therefore seems to suggest that Beat poetry is best regarded as both a reaction against modernism and a continuation, 
reclaiming and reinterpretation of the avant-garde ideals of modernism - in which the origins of postmodernism is to be found. In this several other research possibilities are to be found. For example, an investigation of Beat poetry's continuities with the modernist avant-garde (in terms of, for example, imagism and surrealism) would also make a productive and useful contribution to the continuing discourse surrounding the literary-historical dimension of the Beat movement.

There are also several research possibilities relating to the relationship between Beat poetry and South African poetry. There is a direct link between Beat poetry and South African English poetry in the person of Beat poet Sinclair Beiles, who, in the late 1950s and early 1960s, collaborated with William S. Burroughs and Brion Gysin in developing the cut-up technique. Beiles published a number of collections of plays and poetry, including $A$ South African abroad (Beiles, 1991). While there has been some interest in Beiles's work (see Finlay, 1997), opportunities for research remain largely unexplored. In the broader South African literary context, Beat influences may be seen in a number of contemporary South African poets' writing (especially Afrikaans poets; see Kruger, 2006), which open additional avenues for further research.

\section{List of references}

ALLISON, A.W., BARROWS, H., BLAKE, C.R., CARR, A.J., EASTMAN, A.M. \& ENGLISH, H.M., eds. 1983. The Norton anthology of poetry. New York: Norton.

ALTIERI, C. 1996. What is living and what is dead in American postmodernism: establishing the contemporaneity of some American poetry. Critical inquiry, 22:764-789.

ASHER, L. 1997. Allen Ginsberg. www.charm.net/ brooklyn/People/Allen Ginsberg.html Date of access: 7 Feb. 1998.

AUSTIN, J. 1995. Introduction to liner notes for Holy soul jelly roll - poems and songs 1949-1993. www.rhino.com/features/liners/71693lin.html Date of access: 19 Feb. 1998.

BEILES, S. 1991. A South African abroad. Venice: Lapis.

CALINESCU, M. 1987a. Five faces of modernity: modernism, avant-garde, decadence, kitsch, postmodernism. Durham: Duke University Press.

CALINESCU, M. 1987b. Introductory remarks: postmodernism, the mimetic and theatrical fallacies. (In Calinescu, M. \& Fokkema, D., eds. Exploring postmodernism: selected papers presented at a workshop on postmodernism at the XIth International Comparative Literature Congress,

Paris, 20-24 August 1985. Amsterdam: John Benjamins. p. 3-16.)

CAMPBELL, J. 1999. This is the Beat generation: New York, San Francisco, Paris. London: Secker \& Warburg. 
CARTER, D., ed. 2001. Spontaneous mind: selected interviews 1958-1996. London: Penguin.

CHARTERS, A. 1993. Beat poetry and the San Francisco Poetry Renaissance. (In Parini, J. \& Millier, B.C., eds. The Columbia history of American poetry. New York: Columbia University Press. p. 581-604.)

CLARK, T. 1970. Interview with Allen Ginsberg: "The art of poetry". (In Hamalian, L. \& Karl, F.R., eds. The radical vision: essays for the seventies. New York: Crowell. p. 129-165.)

EVERSON, W. 1981. Dionysus and the Beat generation and four letters on the archetype. (In Bartlett, L., ed. The Beats: essays in criticism. London: McFarland. p. 181-194.)

FIEDLER, L. 1992 [1972]. Cross the border - close the gap. (In Waugh, P., ed. Postmodernism: a reader. London: Arnold. p. 31-48.)

FINLAY, A. 1997. Book reviews: recent poetry, S. Beiles; The Beat hotel exhibition, Carfax, Johannesburg; Video - Sacred fix: the life and work of Sinclair Beiles. New coin, 33(1):93-96.

GÉFIN, L. 1984. Ellipsis: the ideograms of Ginsberg. (In Hyde, L., ed. On the poetry of Allen Ginsberg. Ann Arbor: University of Michigan Press. p. 272287.)

GEORGE, P.S. \& STARR, J.M. 1985. Beat politics: new left and hippie beginnings in the post-war counterculture. (In Starr, J.M., ed. Cultural politics: radical movements in modern history. New York: Praeger. p. 189234.)

GILMORE, M. 1997. Allen Ginsberg: 1926-1997. Rolling Stone, 761:34-38.

GINSBERG, A. 1984a. Collected poems: 1947-1980. New York: Harper \& Row.

GINSBERG, A. 1984b. Notes written on finally recording "Howl". (In Hyde, L., ed. On the poetry of Allen Ginsberg. Ann Arbor: University of Michigan Press. p. 80-83.)

GINSBERG, A. 1995. Notes on selected poetry vocalized (liner notes for Holy soul jelly roll - poems and songs 1949-1993.) www.rhino.com/ features/liners/ 71693lin.html Date of access: 19 Feb. 1998.

HOLMES, J.C. 1981. Unscrewing the locks: the Beat poets. (In Bartlett, L., ed. The Beats: essays in criticism. London: McFarland. p. 5-13.)

HUNSBERGER, B. 1984. Kit Smart's Howl. (In Hyde, L., ed. On the poetry of Allen Ginsberg. Ann Arbor: University of Michigan Press. p. 158-170.)

HUYSSEN, A. 1986. After the great divide: modernism, mass culture, postmodernism. Bloomington: Indiana University Press.

JACKSON, C. 1988. The counterculture looks East: Beat writers and Asian religion. American studies, 29(1):51-70.

KEROUAC, J. 1995 [1953]. Essentials of spontaneous prose. (In Charters, A., ed. The portable Jack Kerouac. London: Viking. p. 484-486.)

KRUGER, H. 2006. 'n Suid-Afrikaanse Beat: The Buckfever Underground en Toast Coetzer. Stilet, 18(2):78-101.

LEE, A.R., ed. 1996. The Beat generation writers. London: Pluto.

LYOTARD, J.-F. 1984. The postmodern condition: a report on knowledge. (Trans. by G. Bennington and B. Massumi). Manchester: Manchester University Press.

LYOTARD, J.-F. 1993. Answering the question: what is postmodernism? (In Docherty, T., ed. Postmodernism: a reader. New York: Columbia University Press. p. 38-46.) 
MOORE, J. 1997. Public heart: an interview with Allen Ginsberg. www.bookwire.com/hmr/REVIEW/moore.html Date of access: 2 Feb. 1998.

MORGAN, B., ed. 2000. Deliberate prose: selected essays 1952-1995. London: Penguin.

PEABODY, R., ed. 1997. A different Beat: writings by women of the Beat generation. New York: Serpent's Tail.

PIVANO, F. 2001 [1968]. Interview with Allen Ginsberg. (In Carter, D., ed. Spontaneous mind: selected interviews 1958-1996. London: Penguin. p. 103-123.)

PORTUGÉS, P. 1984. Allen Ginsberg's Paul Cézanne and the Pater Omnipotens Aeterna Deus. (In Hyde, L., ed. On the poetry of Allen Ginsberg. Ann Arbor: University of Michigan Press. p. 141-157.)

PROTHERO, S. 1991. On the holy road: the Beat movement as spiritual protest. Harvard theological review, 84(2):205-222.

RASKIN, J. 2005. American scream: Allen Ginsberg's Howl and the making of the Beat generation. Berkeley: University of California Press.

ROBEY, D. 1986. Anglo-American New Criticism. (In Jefferson, A. \& Robey, D., eds. Modern literary theory: a comparative introduction. London: Batsford. p. 73-91.)

RUSSELL, C. 1985. Poets, prophets and revolutionaries: the literary avantgarde from Rimbaud through postmodernism. New York: Oxford University Press.

SANDERS, A. 2000. The poetry and life of Allen Ginsberg: a narrative poem. London: Simon \& Schuster.

SMITH, D. 1996. How Allen Ginsberg thinks his thoughts (originally published in The New York Times, Oct. 8 1996). www.english.upenn.edu/ afilreis/88/ ginsberg-nyt.html Date of access: 14 April 2005.

STEPHENSON, G. 1990. The daybreak boys: essays on the literature of the Beat generation. Carbondale: Southern Illinois University Press.

TYTELL, J. 1976. Naked angels: the lives and literature of the Beat generation. New York: McGraw-Hill.

WATSON, S. 1995. The birth of the Beat generation: visionaries, rebels, and hipsters: 1944-1960. New York: Pantheon.

\section{Key concepts:}

Beat poetry

Ginsberg, Allen

modernism

postmodernism

Kernbegrippe:

Beatpoësie

Ginsberg, Allen

modernisme

postmodernisme 